\title{
THE REGIONAL LEVEL IN THE ROMANIAN AND FRENCH LAW - COMPARATIVE STUDY
}

\section{Elena SFERLEA}

\section{E. SFERLEA}

\section{Agora University of Oradea}

Faculty of Juridical and Administrative Sciences, Romania

*Correspondence: Agora University of Oradea, 8 Piaţa Tineretului St., Oradea, Romania

E-mail: ileanamarcu@gmail.com

\begin{abstract}
The present paper outlines a comparative study on the regional level as stipulated by the Romanian and French legislations. It aims to identify the main similarities and differences between the Romanian development regions and the French regions, although Romania does not have a real administrative regional level. The study also considers the particular territorial features of the two states, along with the specific trends they are following in their administrative-territorial reorganization and which can determine different evolutions.
\end{abstract}

KEYWORDS: development regions, region, territorial collectivity, administrative-territorial organization/reorganization, decentralization, administrative level, county, competences

\section{INTRODUCTION}

Territorial organization in Romania and France relies on the same principles, such as territorial uniformity, coexistence in the same territory of a decentralized administration along with a deconcentrated one, but also two common administrative levels: the basic level (commune) and county level. In France, there is also a third level of territorial administration - regional administration, which does not quite have a proper correspondent in Romania, because the development regions do not enjoy the status of territorial community.

The great number of communes, the various territorial collectivities led by specific regimes and the development of inter-communality increase the complexity of the French administrative environment. The collectivities that are in derogation of the common law, the collectivities with particular status, the overseas collectivities as provided by Art.74 of the Constitution, or the collectivities with uncertain status embody the numerous particularities of the French territorial administration.

In turn, the territorial organization of Romania is less complicated. At basic level, the commune and the town make the distinction between rural and urban. Based on their development and the population density, the major Romanian towns are converted into municipalities. Stipulated facultatively for all municipalities, the administrative-territorial divisions do not exist literally outside the capital-city where they are named sectors. The capital-city of Romania has 6 sectors while the number of arrondissements in Paris, Lyon and Marseille is greater (20, 16 and 9, respectively). In both countries, the capital-city enjoys a special status ${ }^{1}$.

At county level, the Romanian Constitution confers the County Council the particular status of coordinator and also provides the traditional county pattern which distinguishes it from the French département. For France, highly important is also the election of the county

\footnotetext{
${ }^{1}$ The law of February $28^{\text {th }} 2017$ on the status of Paris and metropolitan planning, known as the Paris Act, relaxes the criteria for access to metropolitan status. Unlike French legislation, in Romanian system there is no law dedicated exclusively to Bucharest, but a separate regulation in the Law on Local Public Administration No. $215 / 2001$
} 
counselors (former general counselors) at canton level. In terms of the number of communities at every level and their territorial and demographic characteristics, the discrepancies between territorial collectivities within the same division are more evident in France.

A relatively flexible and progressive legal framework has been created to meet the diversity of the French territorial collectivities, framework which does not ignore various autonomist trends expressed by the overseas population. The less complicated configuration of the Romanian territorial administration is given by the reduced number of territorial divisions and collectivities within the same division, but also the presence of the quite isolated derogatory situations. Of the utmost importance is the fact that the Constitution currently in force strengthens especially the local autonomy ${ }^{2}$ of the basic administration level, whereas the county governing body receives the mission to coordinate the whole range of county public services. Marked by the past experience of centralization, this approach of the Romanian lawmaker reveals the strong desire to provide more freedom to the local administration.

\section{THE FRENCH REGION - THE TERRITORIAL COLLECTIVITY OF THE FUTURE (?) - THE ROMANIAN DEVELOPMENT REGION - A SIMPLE COOPERATION BETWEEN COUNTIES}

Provided by the Constitution following the revision of March 2003, the French regions were converted into territorial collectivities by the Law of March $2^{\text {nd }} 1982$. At that time, France had 21 metropolitan regions regulated by Law no. 86-16 of January $6^{\text {th }} 1986$ and 4 overseas regions whose territory matched that of the overseas départements (Law no.82-1171 of December $31^{\text {st }} 1982$ concerning the organization of the Guadeloupe, Guiana, Martinique and Reunion regions). Although the provisions regarding Corsica are part of the General Code of Territorial Collectivities which regulates the regions, Corsica falls in the category of the collectivities that hold special status along with Ile-de-France and other overseas regions. ${ }^{3}$ While the special feature of the overseas regions is that they make up a unitary département, the metropolitan regions are completely different.

In spite of the controversial debates and rivaling opinions that it had stirred, on $17^{\text {th }}$ of December 2014, the French National Assembly adopted unappealable the map of the 13 French regions, reform which came into force in 2016. The purpose was to create Europeanlevel regions able to generate economic development. The adopted document ${ }^{4}$ also amended the mechanism that allowed a département to change the region it belonged to, by removing the requirement of the local referendum. But this right to make a choice involves the consent of the two involved regional councils, as well as the consent of the departmental council with a three-fifths majority. As the project is unfinished, other future transfers of competence are planned to the benefit of these regions. ${ }^{5}$ In particular, the Law "NOTRe" on the New Territorial Organisation of the Republic, enacted on August 7th 2015 confers new competences to the regions and clearly redefines the competences assigned to every category of territorial collectivity. ${ }^{6}$

The region is the newest common law collectivity of France, created based on the existing départements. Being conferred at the very beginning the status of specialized public establishment by Law no.72-619 of July 5th 1972, it became territorial region in full exercise

\footnotetext{
2 For the first time in the modern history of Romania, this principle was stipulated by the Constitution of 1991.

3 M. Verpeaux, Droit des collectivités territoriales, PUF, Paris, 2005, p. 46.

4 Law of January $16^{\text {th }} 2015$ concerning the delimitation of regions, the regional and departmental elections, voted in 2014, which also modifies the election calendar.

5 It concerns the administration of departmental colleges, school transportation, roads and harbors.

6 It concerns the third stage of territorial reform, desired by the President of the Republic, following the Law regarding the modernization of the territorial public action and the creation of the metropolis, and the Law on the delimitation of regions.
} 
on March 16th 1986, which also marked the first election of the regional counsellors based on a direct universal suffrage. While in France this new category of territorial collectivities is stipulated by law, its creation in Romania would involve a revision of the Fundamental Law of Romania. The Constitution does not stipulate the competence of the lawmaker in this matter. Moreover, Art.3 paragraph 3 of the Constitution concerning the administrative organization of the territory is interpreted in a restrictive manner.

Also based on the current counties, the 8 Romanian development regions, pursuant to Law no.151/1998, can develop nothing more than a cooperation between the counties. Art.5 paragraph 2 of the new Law no. 315/2004 on the regional development in Romania, clearly stresses that „they are not administrative-territorial units ${ }^{7}$ and have no legal status”. The development regions are intended to represent the framework for the elaboration, implementation and evaluation of the regional development policy, and for collecting the specific statistical data according to European regulations issued by EUROSTAT for NUTS 2"8 (Art.6 paragraph 2 of the new Law no. 315/2004). The initial purpose of the French region was to act as ,an instance meant to coordinate, schedule and organize the development process" $"$ and whose competences were specialized. The enactment of Law NOTRe in August 2015 redefined the competences and responsibilities of the French regions. ${ }^{10}$

The presence of the regional collectivity has generated debates on the relevance of the county and the overlapping of different territorial administrative levels. Although these debates have been less visible in Romania, the Government Decision no.229/2017 concerning the new General Decentralization Strategy might stir them. This body of law is intended to prepare the transfer of new exclusive competences to the local authorities. ${ }^{11}$

With the exception of Bucharest-Ilfov no other Romanian development region comprises less than 4 counties (the Western region case), as compared to its French counterpart where several regions had only two departments (Alsacia, Nord - Pas-de-Calais, Haute-Normandie or Corsica, but the latter can be referred to as a region) before the regional reform. Following its division into 13 regions Corsica has become the only French bi-departmental region. Every new region comprises 7.3 departments. ${ }^{12}$ The average surface of a Romanian development region is about $33795 \mathrm{~km}^{2}$ except for Bucharest-Ilfov. ${ }^{13}$ In Metropolitan France ${ }^{14}$ the average surface of a region had been of about $25903 \mathrm{~km}^{2}$, before their number was reduced in 2014 . Considering the DOM/ROM, the average surface of the NUTS 2 French regions ${ }^{15}$, as shaped

7 In the Romanian legal terminology, the term "administrative-territorial unit" has two meanings: territorial collectivity and state administrative circumscription. With origins going back to the communist regime, the notion highlights the double nature of the commune, city or county as provided by the Romanian law.

8 According to the official Eurostat site, NUTS is a three-level classification. It divides each memberstate into a whole number of NUTS 1 regions, each of the latter being subsequently sub-divided into a whole number of NUTS 2 regions, etc. The NUTS regulation also sets the minimum and maximum population limit for the medium-size NUTS regions. For the NUTS 2 level, the minimum limit is of 800,000 inhabitants while the maximum limit reaches 3 million inhabitants. Considering the differences in the number of population between the various French regions, as shaped initially, they correspond to NUTS 1 and 2 levels. After the reform, population gaps between regions were reduced.

9 P. Sadran, La région, in Les Cahiers français $\mathrm{n}^{\circ}$ 239, janvier-février 1989, La documentation Française, Paris, 1989, p. 28.

10 They are in charge of: establishing the regional economic development, innovation and internationalization plan; coordinating the support provided to tourism; devising a land use and sustainable development plan; strengthening its role in non-urban transportation.

11 They involve fields like agriculture, education, health, culture, environment, youth and sport, tourism.

12 Source: http://geoconfluences.ens-lyon.fr/actualites/eclairage/regions-francaises, accessed at the beginning of October 2017.

13 NSI, Statistical Yearbook 2006.

14 According to NSI, its total surface is $543965 \mathrm{~km}^{2}$.

15 Source: the official Eurostat site. 
initially, is of $24356 \mathrm{~km}^{2}$. The French actual regions have almost doubled their surface since their creation (their average surface is of $44600 \mathrm{~km}^{2}$ ).

Apart from Ile-de-France whose population exceeds 11.5 million inhabitants, the population density in the French regions was on average 2483800 inhabitants in the Metropolitan France ${ }^{16}$ before the reshaping of the regional map, and about 4.8 million inhabitants ${ }^{17}$ after this date. According to the Census of $2012^{18}$ the average number of stable population in the Romanian development regions is of about 2.7 million inhabitants. On January $1^{\text {st }} 2017$, the most populated Romanian development region was the North-Eastern Region (3 238910 inhabitants) while the less populated area was the Western Region (1 791922 inhabitants). ${ }^{19}$ Over the last years, there has been an obvious decline in the Romanian population density, while in the new French regions the trend is positive. According to the French Census of $2007^{20}$, the most populated region is Ile-de-France (11 740138 inhabitants) whereas the region with the most scarce population is Limousin ${ }^{21}$ (759 414 inhabitants) in Metropolitan France and Guyane (215 036 inhabitants) in the overseas regions. After the reform, Corsica has become the less populated French region (over 300000 inhabitants). Comparing the number of regional population in the two countries, there is a more striking contrast between the French regions, although before the fusion these regions were smaller than the Romanian development regions, and larger after this moment.

Before 2013, the doctrine emphasized the "adoption [in France] of a territorial pattern that has determined the creation of "small regions" (around 20 for the metropolis instead of 5 or 6 as initially considered based on economic criteria)" and raised the issue of cooperation between neighboring regions. ${ }^{22}$ In addition, we should also mention the great demographic discrepancies which "justify the difficulties encountered in the implementation of land use policies due to the strong concentration around Paris and some large cities". ${ }^{23}$ Considering the small number of comparative studies based on figures, the idea that the French regions are weaker than their German, Spanish or Italian counterparts is sometimes challenged". ${ }^{24}$ However, we must acknowledge its contribution to the recent fusion of some regions and to the reshaping of the regional map.

In Romania, a certain reluctance of the politicians to a potential regionalization of the country, the need for constitutional revision in this matter, and the risk to overlap different territorial administration levels considering the smaller surface of Romania as compared to France, could delay the creation of regions. However, the draft law which proposes a new regional organization in Romania, approved by the Senate in February 2010 by tacit acceptance procedure, seems to demonstrate the contrary. ${ }^{25}$ While in France, the reform of territorial collectivities initiated in 2013 encourages the regional clusters in order to increase their size

\footnotetext{
16 NSI, the Census of 1999 and some estimates made on January $1^{\text {st2 }} 2006$.

$17 \quad$ NSI, data from 2011.

18 Source: www.insse.ro, Census of population and dwellings of 2002.

19 NSI, 2017.

20 www.insee.fr.

21 Aspect perfectly available if we don't consider Corsica a region.

22 J. Moreau, Administration régionale, départementale et municipale, 14ème éd., Dalloz, Paris, 2004, p. 215.

23 M. Verpeaux, La région, Dalloz, Paris, 2005, p. 28.

24 J.Ziller, Fragmentation/participation : quelle bonne dimension?dansPouvoirs $\mathrm{n}^{\circ}$ 95, La commune en France et en Europe, Seuil, Paris, 2000, p. 20.

25 Initiated by the Democratic Union of Hungarians in Romania and submitted to the Parliament in June 2009 , this project proposes the reorganization of the Romanian development regions. The initiators aim to create 16 regions grouped in 5 macro-regions. But the project was strongly criticized by the opposition due to its attempt to regionalize the country based on ethnic criteria. Thus, Region 14 would have a preponderantly Hungarian population and would aim to recreate the old Hungarian autonomous Region of Mureș(1952-1968). In March 2010, this body of law received a negative opinion from the Judicial Commission of the Chamber of Deputies.
} 
and competitiveness, in Romania, there is an opposite tendency which aims to rise the number of regions from 8 to 16, although the latter would finally be reorganized in 5 macro-regions.

\section{CONCLUSIONS}

While the region could be perceived as the territorial collectivity of the future in the Hexagon, its creation would involve a constitutional revision in Romania and would generate such complications like the overlapping of two intermediate territorial administration levels. The current Romanian development regions serve as framework for the implementation of regional development policies and especially for accessing community financing. In search of an optimal collectivity size, the debates on the reform of the administrative map are considerably stronger in France and they concern in particular the relevance of the departmental collectivity. Even if the communal division is an issue that particularly France has been dealing with for a long time, both countries promote an intercommunal cooperation policy which is in its early stages in Romania.

Over the last years, the two countries have experienced different trends in the matter of administrative-territorial reorganization. While in Romania, a controversial draft law proposes the doubling of the current number of development regions, the Law of December $16^{\text {th }} 2010$ on the reform of French collectivities encourages the fusion of the counties and regions in order to increase their size and power. The reshaping of the regional map made in 2014 reduced by a third the number of French regions. Also, the conversion after 1990 of more than 60 Romanian communes into towns, while about 2000 town halls had serious difficulties in paying current financial obligations from their own budget ${ }^{26}$, opposes the idea of a strong French Metropolis, according to MAPTAM Law, voted in 2013, which provided the existence of 13 metropolises. Nevertheless, a positive trend can be noticed at intercommunal level in both countries, although in Romania it is just an early stage because the intercommunity development associations are private law entities and only, by way of derogation, public utility entities.

We would like to stress again that, formally, the implementation of a new administrativeterritorial organization in Romania requires the revision of the current Constitution which legitimizes only restrictively the administrative division of the national territory. Upon its accession to EU, Romania committed to maintain its regional organization until 2013. The public consultation and the consent of the member counties are prerequisites to any amendment in this matter. At the same time, politicians have different opinions when it comes to the need for an administrative reorganization of Romania. It is interesting to find out the potential change generated by the draft of the Romanian Administrative Code sent for public consultation in November 2016, or the implementation of the recent General Decentralization Strategy.

In France, the simplification and relief of the territorial configuration are considered a real necessity and the main objective out of the three aimed by the collectivity reform promoted by the Fillon government and its successor. The purpose is thus to create two different poles: counties - region and communes - inter-communality. In 2014, the same politicians are members of the Departmental Council (ex-General Council) and of the Regional Council. The division of competences between the department and region is carried out by clearly defined principles which are meant to prevent overlapping. Intercommunal regrouping is also encouraged considering that the intercommunal coverage of the national territory had to be accomplished by January $1^{\text {st }} 2014$. More power was also granted to prefects. Due to the foreign territorial competition and based on a voluntary communal initiative, the French metropolises have been created, which hold the status of public establishments for

26 In this context, it is worth mentioning the adoption of the Emergency Governmental Ordinance no.43/2013 on the financial crisis and insolvability of the administrative-territorial units. 
intercommunal cooperation (ICPE) in which the integration of competences and financial framework is strengthened. The public establishment for intercommunal cooperation with their own fiscalism can create "metropolitan poles", structures that are managed by mixed syndicates. Last but not least, the accession of territorial collectivities to multiple financing programs is regulated by the law.

Nowadays, the French regions are smaller in number, but larger and less unequal in spite of their inner heterogeneity. ${ }^{27}$ The challenges they are facing mainly concern their financial means and the limited number of competences that they can exercise. Their role demonstrates another ongoing decentralization process, just like in Romania. The deployment of all these changes made by the adoption of several successive laws facilitates an important evolution, especially in terms of the structure of the administrative map of France whose current complexity still raises lots of issues.

\section{BIBLIOGRAPHY}

1. Brennetot A., de Ruffray S., Une nouvelle carte des régions françaises, Université de Rouen, 30 septembre 2015, accessible on http://geoconfluences.enslyon.fr/actualites/eclairage/regions-francaises

2. Constantinescu M., Iorgovan A., Muraru I., Tănăsescu E. S., Constituţia României revizuită - comentarii şi explicaţii, All Beck, Bucarest, 2004

3. Moreau J., Administration régionale, départementale et municipale, 14ème éd., Dalloz, Paris, 2004

4. Sadran P., «La région », dans Les Cahiers français $\mathrm{n}^{\circ}$ 239, janvier-février 1989, La documentation Française, Paris, 1989, p. 28

5. Verpeaux M., La région, Dalloz, Paris, 2005

6. Verpeaux M., Droit des collectivités territoriales, PUF, Paris, 2005

7. Ziller J., Fragmentation/participation: quelle bonne dimension? Dans Pouvoirs $\mathrm{n}^{\circ}$ 95, La commune en France et en Europe, Seuil, Paris, 2000, pp. 19-31

8. Online sources: www.insee.fr, www.ec.europa.eu/eurostat, www.insse.ro, www.cdep.ro, www.gov.ro, www.lemonde.fr, www.ccomptes.fr, www.collectivites-locales.gouv.fr/

9. Rapport de la Cour des Comptes sur la situation financière et la gestion des collectivités territoriales et de leurs établissements publics, octobre 2017.

27 A. Brennetot, S. de Ruffray, Une nouvelle carte des régions françaises, Université de Rouen, 30 septembre 2015, accessible on http://geoconfluences.ens-lyon.fr/actualites/eclairage/regions-francaises. 